\title{
A BOT FLY FROM THE WHITE-FOOTED MOUSE
}

\author{
By Charles W. Johnson \\ Boston Society of Natural History
}

In July, 1930, Dr. Langdon Frothingham presented to the collection of the Boston Society of Natural History a bot fly-Cuterebra (Bogeria) fontinella Clark, obtained from a White-footed Mouse (Peromyscus leucopus noveboracensis Fischer). The following note was furnished by Dr. Frothingham: "The larva of the bot fly, which formed a large swelling on the thigh of the mouse, left its host August 26, 1929, was placed in a small jar of damp earth, and almost immediately buried itself in the earth. It was left in my closed summer cottage at Pocasset over the winter. The earth was dampened twice in the fall, September and October, and again in June and July. The fly emerged on July 15, 1930."

The fly is $15 \mathrm{~mm}$. in length and represents the smallest of our species of Cuterebra. It agrees in every respect with C. fontinella Clark as defined by E. E. Austin, ${ }^{1}$ but not with Bogeria fontinella Clark as described by Townsend. ${ }^{2}$ The standing of Bogeria even as a subgenus is questionable. The chief character, "arista bare," used by Austin having proved to be erroneous, Townsend took up a second character, "antennal pit," used by. Austin to separate Bogeria from Rogenhofera. This character when confined to Cuterebra has evidently no generic value.

This is the first record to my knowledge of this bot fly having been actually obtained from the White-footed Mouse, although the larvæ of Cuterebra have been found in this Mouse at Sandwich, Mass., by Willard Reed; at Wareham, Mass., by Outram Bangs; and at Bedford, Mass.,

${ }^{1}$ Annals and magazine of Nat. History, ser. 6, vol. 15, 1895.

${ }^{2}$ Insecutor Inscitiæ Menstruus, vol. 5, p. 27, 1919. 
by J. Miller. Riley and Howard ${ }^{3}$ record Cuterebra larvæ from a mouse-Sitomys californicus at West Creek, California. Larvæ of this genus have also been found in the Meadow Mouse at Provincetown, Mass. I remember that while living in Florida I obtained Cuterebra larvæ from the large wood rat.

The life history of the Cuterebrinæ is quite different from the other subcutaneous bots. The flies appear from May to July and deposit their eggs, the larvæ maturing quite rapidly, leaving their hosts in August and September, and passing the winter in the ground as pupæ.

The abundance of bots on the Barren-ground Caribou (Rangifer caribou Gmelin) in Labrador is well illustrated by a skin recently tanned for Mr. Francis Richardson. A piece $7 \times 10$ inches presented to the Museum shows over 200 perforations, the number in the entire skin far exceeding 1000. About one-third of these entirely perforated the skin, the others represented scars of older perforations that had healed. Judging from the antlers the caribou was probably about eight years old. The bot fly in all probability is Oedemagena tarandi Linn., although a similar species O. terrænovæ Knab, is found in Newfoundland infesting Rangifer terrænovæ Bangs.

${ }^{3}$ Insect Life, vol. 6, p. 47, 1893. 

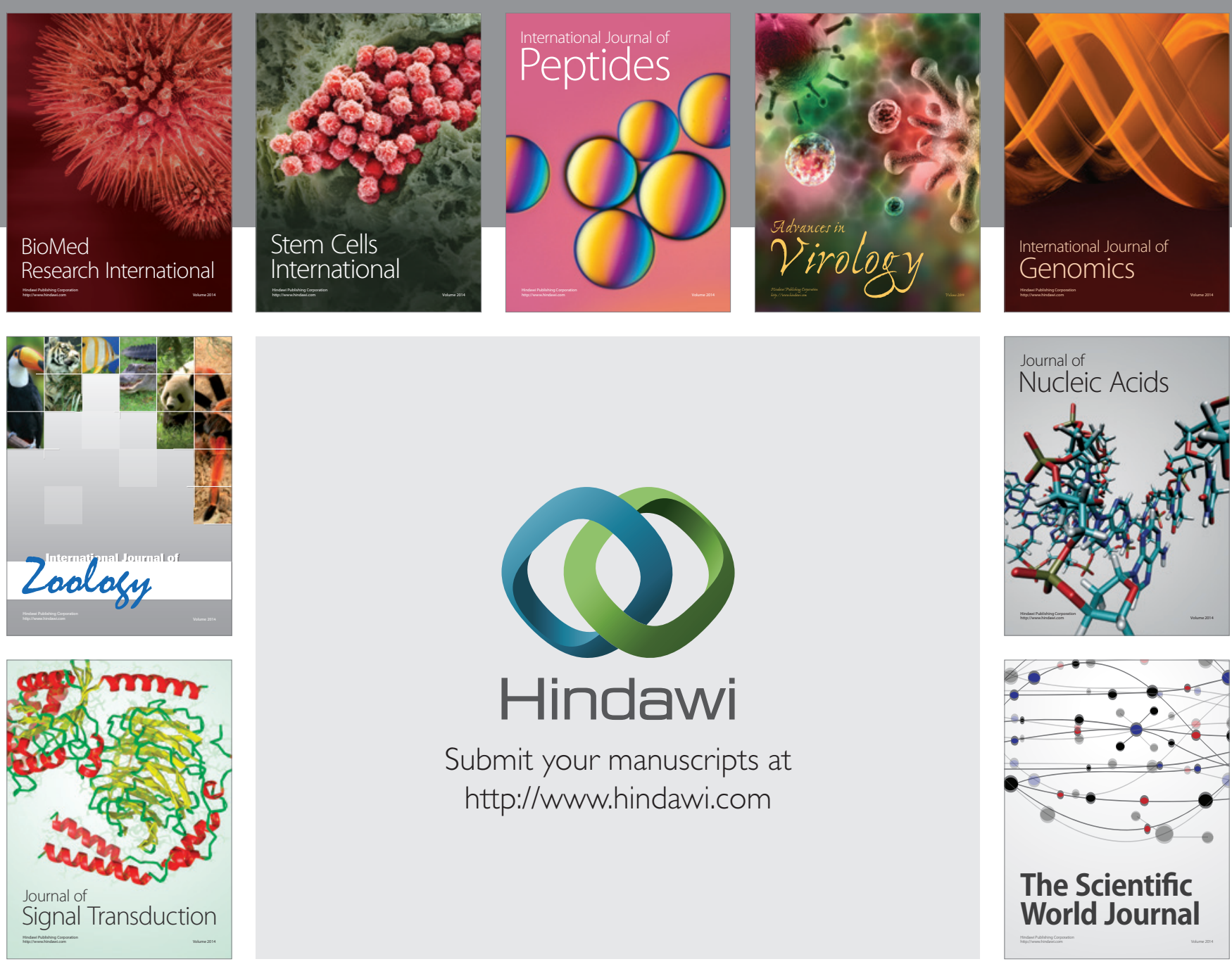

Submit your manuscripts at

http://www.hindawi.com
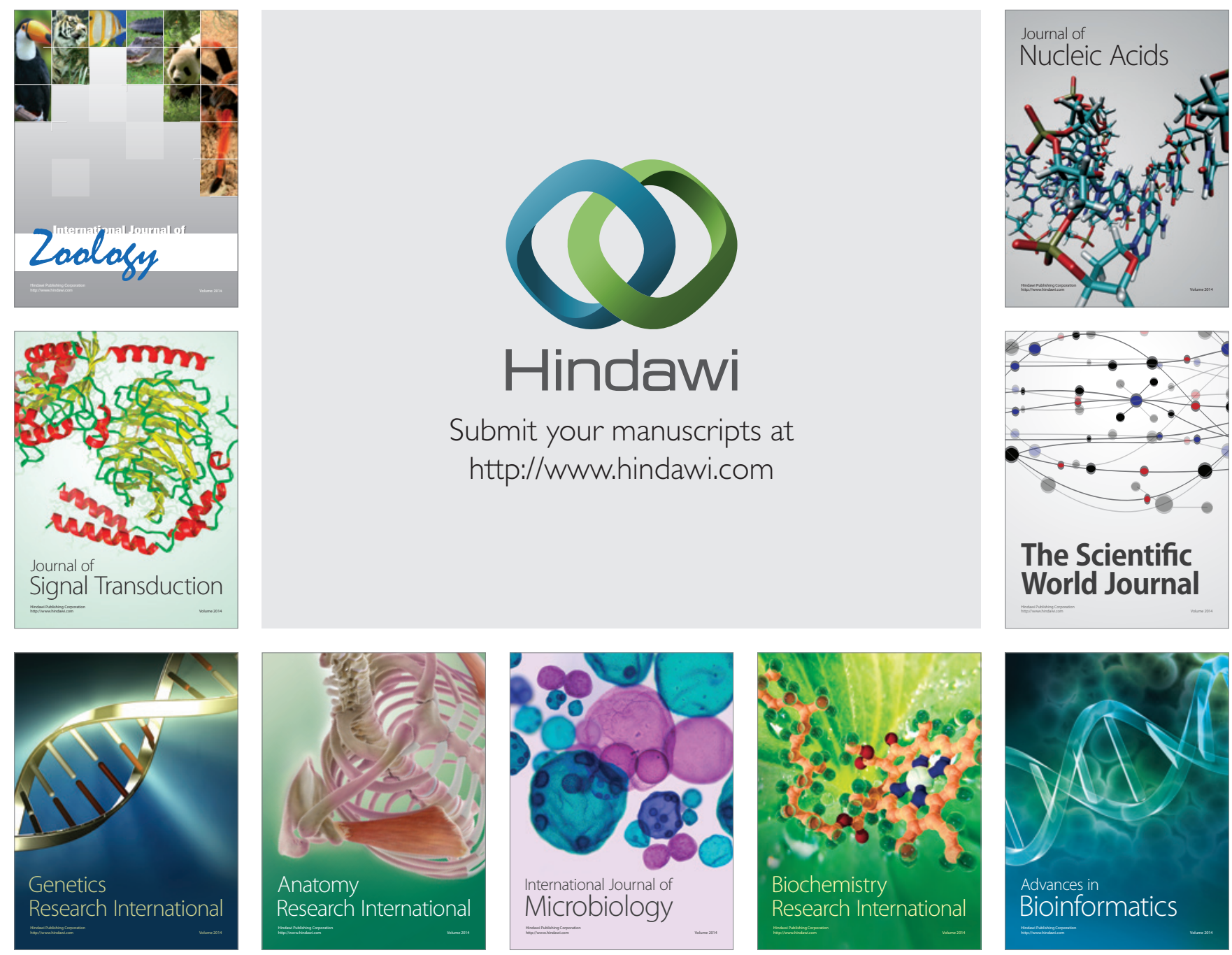

The Scientific World Journal
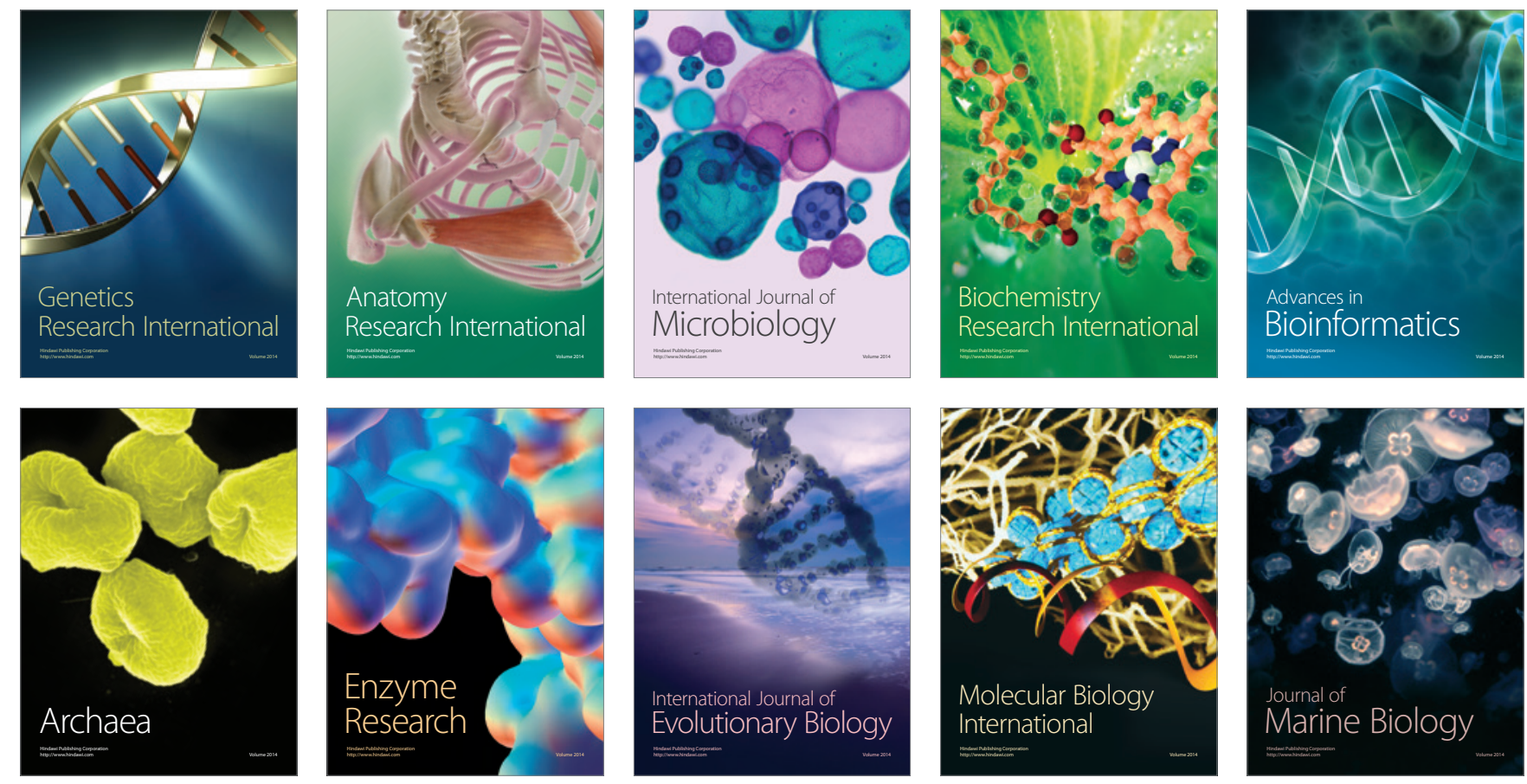